\title{
PEG Induced Germination, Seedling Growth and Water Relation Behavior of Wheat Genotypes under Salt Stress Condition
}

\author{
Md. Abdullahil Baque ${ }^{1, *}$, Most. Faijunnahar ${ }^{1}$, Md. Ahsan Habib ${ }^{1}$, Mahmuda Motmainna² \\ ${ }^{1}$ Department of Agronomy, Faculty of Agriculture, Sher-e-Bangla Agricultural University, Bangladesh \\ ${ }^{2}$ Agriculture Extension Officer, Kaligonj, Lalmonirhat, Bangladesh
}

Copyright $\mathrm{C} 2018$ by authors, all rights reserved. Authors agree that this article remains permanently open access under the terms of the Creative Commons Attribution License 4.0 International License

\begin{abstract}
Pre-sowing seed treated with Polyethylene Glycol (PEG) believed to be a potential priming agent to increase the germination, seedling growth and water relation behavior of crop plants under salt stress condition. With this view, a lab investigation was carried out to find out the effect of PEG on the germination, seedling growth and water relation behavior of wheat under different salt levels. Seeds of ESWYT 5, ESWYT 6 wheat genotypes and BARI Gom 28 were pre-soaked in $10 \%$ PEG solutions for $9 \mathrm{~h}$ and allowed to grow under 5 levels of salt concentrations viz.,0, 5, 10, 15 and $20 \mathrm{dSm}^{-1}$. Findings of the research work showed that seed priming with $10 \%$ PEG solution for $9 \mathrm{~h}$ had significant effect on germination, seedling growth and water relation behavior of wheat genotypes under salt stress condition. Among three wheat genotypes, ESWYT 5 performed the best regarding germination, seedling growth and water relation behavior where wheat genotypes ESWYT-6 performed moderately and BARI Gom 28 showed poor performance. With increasing the salinity level the decreasing of germination, seedling growth and water relation behavior was normal phenomena but in this experiment, priming helped to reduce the magnitude of reduction. These results suggest that seed priming had significant effect to trigger the germination, seedling growth and water relation behavior of wheat genotypes under salt stress condition.
\end{abstract}

Keywords Germination, Osmopriming, Polyethylene Glycol, Salt Stress, Wheat Genotype, Water Relation Behavior

\section{Introduction}

Wheat (TriticumaestivumL.), one of the most significant staples food crop, it accounts for about $20 \%$ of the human food supply and is cultivated on approximately 215 million ha globally [1]. Plant has its own defense mechanism under stress condition which is a natural phenomenon, and that is why the yield of crops decreases but helps to enhance the seed quality [2]. Despite the some positive impact of stress but it is not suitable for on seed germination, especially under salt stress. And for this reason, seed priming is considered as an effective means to enhance stress tolerance capability of plant under adverse conditions (especially salinity). Seed priming is a new innovative technique by which some physiological changes are gained into target grain with the use of natural and synthetic compounds prior to germination. The physiological condition of plants in which plants can faster or better activate defense responses or both is called the primed condition of the plant [3]. It optimizes seed performance by rapid and uniform germination, healthy and vigorous seedlings growth reaching a physiological condition resulted in faster and better germination and the emergence of different crops [4,5,6,7]. Carbineau and Come [8] and Ashraf and Foolad [9] reported that, under stress condition primed seedling able to grow normally without any disturbance.

By 2050 the world population will be about 9.10 billion, which will be $34 \%$ higher from today and we need to feed another 2.30 billion people with limited resources. Food production must need to be increased about $70 \%$ and to meet this huge demand cereal production will need to increase about 3 billion metric tons from 2.10 billion metric tons today. But in a dilemma, the world agriculture in $21^{\text {st }}$ century faces versatile challenges such as water, temperature, light, and salts that regulate seed germination interact in the soil interface [10]. These factors may act as stress, leading to injury and even death of the plant in extreme cases [11]. Among the abiotic stress, soil salinity is one of the major abiotic stresses which directly affect plant physiology which causes drastic reduction of crop 
production in saline belt $[12,13]$. World's $25 \%$ cultivable lands are salinity affected among 400 million ha of total land and the salt intrusion scenario is alarmingly increasing. Bangladesh is also not beyond this threat. In Bangladesh the salinity affected area was 83.3 million ha in 1973,102 million ha in 2000 and in 2009 it has reached up to 105.5 million ha and the area is being expanded with times being [14]. The soil salinity may responsible for many detrimental effects on plant growth and development at physiological and biochemical level [15]. In saline soils, seeds with lower osmotic potential fail to absorb water; increase the accumulation of toxic ions ( $\mathrm{Na}+$ and $\mathrm{Cl}-)$ and finally there is a delay, decrease and disruption of seed germination [9]. Metabolism, physiological act and morphological feature of plant changed by soil salinity and drastically reduce the growth and yield [16]. Seed embryo badly affected by higher salt concentration which result there is a delay and reduction of germination percentage of seed. Percentage of germination, length of coleoptiles, length of root and seedling growth reduced by detrimental effect of salinity $[17,18,19,20]$. Cha-um et al. [21] mentioned that plant that was exposed to salinity stress, water potential was reduced then water use efficiency was also reduced.

Priming allows some of the metabolic processes essential for germination to occur without germination take place. During priming, seeds are drenched in various priming solutions. Thus the seeds were prevented from absorbing enough water for radical protrusion and retarding the seeds in the lag phase [7]. Seed priming has been commonly used to minimize the time between seed sowing and seedling emergence and to ensure synchronize emergence [22]. These effects of priming are collaborated with repairing and building up of nucleic acids, increased synthesis of proteins as well as the repairing of membranes [23]. Priming also enhances the activities of anti-oxidative enzymes in treated seeds $[24,25]$. Seed priming can be carried out using different techniques viz. hydro-priming (soaking in distilled water), osmopriming (soaking in osmotic solutions such as $\mathrm{PEG}$, potassium salts, e.g., $\mathrm{KCl}$, $\mathrm{K}_{2} \mathrm{SO}_{4}$ ) and plant growth inducers (CCC, Ethephon, IAA) $[26,27,28,29]$. Under osmopriming (also addressed as osmoconditioning) the seeds are drenched into synthetic compound like: polyethylene glycol (PEG), sorbitol, mannitol solution and let to uptake water to primary metabolic activities of germination process is started, and radical emergence occurred [9]. Osmopriming in the PEG solution allows initiating the membrane repairing systems and metabolic preparation for germination via controlling the water absorption rate of seeds under salt stress condition [30]. Priming increases the activities of glyoxysome enzymes in primed bitter gourd seeds [31]. Faijunnaharet al. [32] and Baqueet al. [33] reported that 10\% PEG was best for enhanced germination behavior of wheat. In many crops, germination and early seedling growth are the most sensitive stages of water deficit caused by salinity stress and the water deficit may delay the onset and decrease the rate and uniformity of germination, leading to reduced crop performance and yield [34]. The beneficial effects of priming may be more evident under unfavorable rather than favorable conditions [22]. These phenomena have empirical agronomic inference especially under adverse germination state in salinity intrusion area [23]. Therefore, the study was carried out to determine the efficacy of PEG as osmopriming agent under salt stress condition and find out the suitable salt stress wheat cultivar(s) for seed industry for successful crop production in different regions especially salt intrusion belt in Bangladesh.

\section{Materials and Methods}

The experiment was carried out in the Central laboratory of the department of Agronomy, Sher-e-Bangla Agricultural University,Dhaka in November, 2016. Temperature range of the laboratory during the experiment was $26.2^{\circ} \mathrm{C}-33.4^{\circ} \mathrm{C}$ and the relative humidity was $56-84 \%$.

\subsection{Plant and Priming Materials}

Three wheat genotypes namely- BARI gom 28, ESWYT-5 and ESWYT -6 were used for this experiment and were collected from seed technology division of Bangladesh Agricultural Research Institute were used as planting material. PEG solution was used as osmo priming agent in this study and $\mathrm{NaCl}$ was used for imposing salt stress condition. Different equipment such as growth chamber, electric balance, Petri dish, filter paper, micro pipette etc. was used for this study.

\subsection{Preparation of Priming Solutions}

$10 \%$ PEG solution and 9 hours priming time were used to test salt stress. $10 \mathrm{~g}$ of PEG was dissolved in $100 \mathrm{ml}$ of water to prepare $10 \%$ solution of PEG. $0.731 \mathrm{~g}$ of sodium chloride (Nacl) was dissolved in $250 \mathrm{ml}$ of distilled water to prepare $5 \mathrm{dsm}^{-1}$ solution of salt (Nacl). Similarly, $1.436 \mathrm{~g}$, $2.18 \mathrm{~g}, 2.925 \mathrm{~g}$ sodium chloride (Nacl) was dissolved in $250 \mathrm{ml}$ ofdistilled water to prepare $10 \mathrm{dsm}^{-1}, 15 \mathrm{dsm}^{-1}, 20$ $\mathrm{dsm}^{-1}$ solution of $\mathrm{NaCl}$, respectively. Distilled water was collected from the laboratory of Sher-e-Bangla Agricultural University (SAU).

\subsection{Seed Placement for Germination}

All seeds were surface sterilized with 2\% Safex solution for 5 minutes, then rinsed with sterilized water and air dried at room temperature. After that seeds were used for priming.

The priming media was prepared in distilled water and $10 \%$ PEG solution and duration of soaking for priming was $9 \mathrm{hr}$. After soaking seeds were air dried and placed in 
Petridish. For each replicate 30 seeds were placed in 12.5 $\mathrm{cm}$ Petridish on a layer of filter paper no. 102 moistened with $8 \mathrm{ml}$ of distilled water.

\subsection{Experimental Design}

The experiment was conducted in Completely Randomized Design (CRD) with five replications. The three wheat genotypes viz., $\mathrm{V}_{1}=$ ESWYT-5, $\mathrm{V}_{2}=\mathrm{ESWYT}$ -6 and $\mathrm{V}_{3}=$ BARI gom 28 screened out from another experiment [35] were examined under five salt concentrations viz. primed seed with $10 \%$ PEG solution for $9 \mathrm{~h}$ under $0,5,10,15$ and $20 \mathrm{dSm}^{-1}$, respectively.

\subsection{Recording of data}

After that data collected on various parameters and mean data of germination percentage, shoot length, root length, shoot dry weight, root dry weight, relative water content, water saturation deficit, water retention capacity, germination coefficient and vigour index were recorded.

Germination was recorded at $24 \mathrm{hr}$ interval and continued up to $11^{\text {th }}$. More than $2 \mathrm{~mm}$ long plumule and radicle seed was considered as germinated seed.

The germination rate was calculated using following formula:

Germination percentage (\%)

$=\frac{\text { TotalNumberofgerminatedseeds }}{\text { Totalseedplaced forgermination }} \times 100$

Germination Co- efficient (GC) was calculated using the following formula [36]:

Germination Co- efficient $(\%)=\frac{A 1+A 2+\cdots+A x}{A 1 T 1+A 2 T 2+\cdots A x T x} \times 100$

Where,

$A=$ Number of seeds germinated

$\mathrm{T}=$ Time corresponding to $\mathrm{A}$

$\mathrm{x}=$ Number of days to final count

Vigour index was calculated using following formula [37]:

Vigour index $=\frac{\text { Totalgermination } \times \text { Seedlinglength }(\mathrm{mm})}{100}$

At $11^{\text {th }}$ day after seed placement, five seedlings of each Petridish were sampled. Shoot and root length of single seedling was recorded with meter scale. Then the shoot and root of the seedling were dried for $48 \mathrm{hr}$ then dry weight of shoot and root were recorded using electric balance.

After recording the fresh weight leaf of each seedling place into Petridish for $24 \mathrm{hr}$ then leaf soaking with distilled water turgid weight was recorded then it was dried for $48 \mathrm{hr}$ the dry weight was measured.

Relative water content was measured using following formula [38]:

Relative water content (WRC) (\%)

$=\frac{\text { Freshweight }- \text { Dryweight }}{\text { Tugidweight }- \text { Dryweight }} \times 100$

Water saturation deficit was recorded using following formula [38]:

Water saturation deficit $(\mathrm{WSD})=100$ - Relative water content
Water retention capacity was measured following formula [38]:

Water retention capacity $($ WTC $)=\frac{\text { Turgidweight }}{\text { Dryweight }}$

\subsection{Statistical Analysis}

The collected data were analyzed statistically following CRD design by MSTAT-C computer package program and the treatments were compared by Least Significance Differences (LSD) test at $1 \%$ level of probability.

\section{Result and Discussion}

\subsection{Germination Percentages}

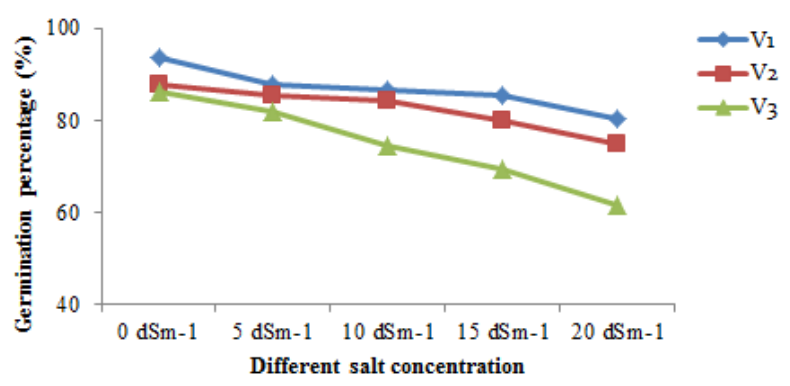

Figure 1. Effect of different salt concentration on the germination percentage of primed wheat cultivars $\left(\operatorname{LSD}_{(0.01)}=6.96,5.47,7.19,5.06\right.$ and 5.09 at $0,5,10,15$ and $20 \mathrm{dSm}^{-1}$, respectively) $\mathrm{V}_{1}=$ ESWYT-5, $\mathrm{V}_{2}=$ ESWYT -6 and $\mathrm{V}_{3}=$ BARI gom 28

Germination percentage of primed (osmopriming) wheat genotypes significantly affected by different level of salinity stress conditions (Figure 1). The germination percentage of primed wheat genotypes was decreased in different extent with increasing the salinity stress. Under different salinity levels wheat genotype ESWYT-5 $\left(\mathrm{V}_{1}\right)$ showed maximum tolerance capability and the magnitude of reduction was slow compare to that of other two genotypes where as BARI Gom $28\left(\mathrm{~V}_{3}\right)$ showed maximum susceptibility and the magnitude of reduction was rapid compare to that of other two genotypes. Wheat genotype ESWYT-6 $\left(\mathrm{V}_{2}\right)$ moderately performed under different saline levels. The result of the experiment revealed that, the maximum germination percentage $(93.81 \%)$ was recorded from wheat genotype ESWYT-5 $\left(\mathrm{V}_{1}\right)$ at $0 \mathrm{dSm}^{-1}$ salt concentrations followed by ESWYT-6 $\left(\mathrm{V}_{2}\right)(87.62 \%)$ and the minimum germination percentage $(61.49 \%)$ was recorded from BARI Gom $28\left(\mathrm{~V}_{3}\right)$ at $20 \mathrm{dSm}^{-1}$ salt concentrations. From the result of the experiment, it was clear that, the germination percentage of primed wheat seed was decreased at an acceptable limit. Similar findings were reported by Kaya et al. [39] and Khajeh-Hosseiniet al. [40]. The germination of wheat genotype could be affected in two ways under salinity condition. First of all, in the germination media excess salt might be reduced the 
osmotic potential of tested seed to such extent that seeds that were placed for germination unable to absorb enough water necessary for transportation of mineral nutrients which were crucial for germination and the second one was is the embryo of the tested seed adversely affected by the toxicity of salt solutes [41]. In the physiological point of view, the absorption of more $\mathrm{K}^{+} / \mathrm{Na}^{+}$is essential for seed germination. The rise of salinity level decreases the $\mathrm{K}^{+} / \mathrm{Na}^{+}$ ratio [42] which injures the embryo of the germinal seed. Khan et al. [43] also reported that, up taking of salt in sensitive plant competes with the up taking of compatible nutrients ions, especially $\mathrm{K}^{+}$, which causes $\mathrm{K}^{+}$deficiency. In salinity stress condition, sensitive wheat genotypes absorb more $\mathrm{Na}^{+}$than $\mathrm{K}^{+}[44,45]$ as a result germination decreases. A wide range of biochemical changes occurred during seed priming which was crucial for germination, i.e., breaking of dormancy, hydrolysis or metabolism of inhibitors, imbibitions and enzymes activation [46]. Primed seed can rapidly consume and resuscitate the seed metabolism under stress conditions; consequently germination percentage was slowly decreased with an acceptable limit with the increasing of salt concentration [47]. Moreover, seed priming most likely grants some fix-up of damage to membrane caused by deterioration by salinity/ drought stress and resulted in better germination pattern and higher vigor level $[30,48]$ with PEG results in strengthening the antioxidant system and increasing the seed germination potential, finally resulting in an increased stress tolerance in germinating seeds of spinach [49]. Despite the negative effects of stress condition, the priming treatment was effective inimproving germination percentage in Presto [50]. Priming showed reviving effects in the early stages of germination by the mediation of cell division in germinating seeds under stress condition. [51]. Similar mechanisms seem to perform in the course of our experiment so that PEG-primed seeds resulted maintain germination attributes to a feasible limit and trigger seedling growth under osmotic stress created by salt intrusion. In many plant species seeds, trypsin-like proteolytic enzymes, which should be produced during seed development, are important during seed development and germination. The activity of such enzymes, however, is often prevented by trypsin inhibitors under stress condition (Saline or drought), which may be present in the seed and play inhibitory roles in protein synthesis during germination. Priming, however, may reduce the regulatory activities of such inhibitory enzymes and boosted the germination of osmoprimed (PEG solution) seed. Soaking sorghum seed in osmoprimed solution decreased the retardant activities of trypsin and chymotrypsin and improved the germination percentage under stress or normal condition. According to McDonald [23] the major pre-germination steps such as DNA and RNA synthesis are accomplished in seeds during the priming states, consequently the seeds are physiologically close to germination and have fewer steps to complete than unprimed seeds. Farooqet al. [52] proposed that physiological changes exerted by osmohardening such as metabolic activities proceed to repair and build up of nucleic acids, increase synthesis of proteins as well as repair membranes, and enhance the activities of anti-oxidative enzymes increased the starch hydrolysis and made more sugars available for embryo growth as a result, the germination capability and tolerance under stress condition (especially salt stress) of seeds can be promoted.

\subsection{Shoot Length}

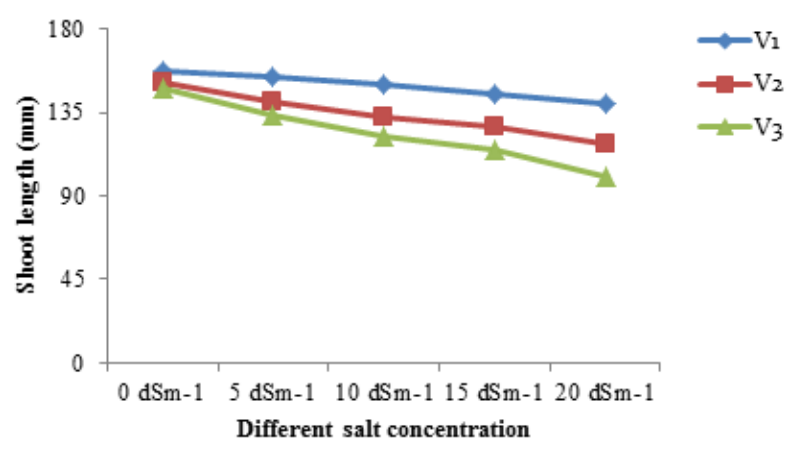

Figure 2. Effect of different salt concentration on the shoot length of primed wheat cultivars $\left(\operatorname{LSD}_{(0.01)}=9.43,5.07,7.94,5.32\right.$ and 7.69 at 0,5 , 10,15 and $20 \mathrm{dSm}^{-1}$, respectively) $\mathrm{V}_{1}=$ ESWYT $-5, \mathrm{~V}_{2}=$ ESWYT -6 and $\mathrm{V}_{3}=$ BARI gom 28

Shoot length of primed (osmopriming) wheat genotypes significantly differed by different level of salinity stress conditions (Figure 2). The shoot length of primed wheat genotypes were decreased in different magnitude with increasing the salinity stress. ESWYT-5 showed highest tolerance capacity and the extent of reduction was slow compare to that of other two genotypes where as BARI Gom 28 showed highest susceptibility and the extent of reduction was rapid compare to that of other two genotypes. Wheat genotype ESWYT-6 moderately performed under different saline levels. The result of the experiment revealed that, the highest shoot length $(157.80 \mathrm{~mm})$ was secured from wheat genotype ESWYT-5 at $0 \mathrm{dSm}^{-1}$ salt concentrations followed by ESWYT-6 $(150.90 \mathrm{~mm})$ and the lowest shoot length $(100.20 \mathrm{~mm})$ was secured from BARI Gom 28 at $20 \mathrm{dSm}^{-1}$ salt concentrations. The shoot length decreased in higher extent for salinity sensitive cultivar compare to the tolerance wheat cultivar might be due to more accumulation of $\mathrm{Na}^{+}$which retard the cell division and elongation process and ultimately reduce the shoot length [35]. Similar findings were reported by Mohammadi and Amiri[53]. Under salinity stress condition the extent of shoot length decrease was lower of wheat seed primed with $10 \%$ PEG solution. The possible cause of lower reduction may be the osmopriming agent PEG which alleviate the adverse effect of salt stress, increased the metabolic activity, trigger the cell division and elongation process consequently reduce the adverse 
effect of salt on shoot growth. Lee and Kim [54] also revealed that, priming increased the metabolic activities of seed consequently produced the substantial shoot length. Faijunnaharet al. [32] and Baque et al. [33] reported that the highest shoot length of wheat was secured when the seed primed with 10\% PEG solution. Experiment conducted by Moghanibashi et al. [55] reported that, as salinity levels increased, shoot length reduces but the priming treatments clearly improved the parameter, so can be used to improve seed performance of sunflower under normal and stress conditions.

\subsection{Root Length}

Different salinity levels had significant influence on the root length of osmoprimed wheat genotypes (Figure 3). The root length of wheat genotypes variably decreased with increasing the salt stress. In case of root length, wheat genotype ESWYT-5 distinctly performed superior under different salinity stress compare to that of other two wheat genotypes on the other hand BARI Gom 28 consistently showed poor performance and ESWYT-6 showed moderate performance. The result of the study revealed that, ESWYT-5 gave the maximum root length (124.60 $\mathrm{mm}$ ) at $0 \mathrm{dSm}^{-1}$ salt concentrations and BARI Gom 28 gave the minimum root length (62.60) $20 \mathrm{dSm}^{-1}$ salt concentrations. Shoot and root length adversely affected by salt stress and as a consequence there was a rapid reduction observed for salinity sensitive genotypes compare to the tolerance one. It has been found that, under slat stress condition photosynthetic rate is reduced markedly, lost huge energy in salt removal mechanism, reduced transportation of compatible nutrient, arrested cell division and enlargement, decreased shoot length, for consequence there was a marked reduction of shoot and root length. Similar findings were also reported by Moud and Maghsoudi [56], Dattaet al. [57], Mujeebet al. [41], Tarmatt and Munns [58] and Dageret al. [59]. Experiments conducted by Ashraf and Abu-shakra [60] revealed that priming of wheat seed in osmoticum might improve germination and emergence and aggrandize vigorous root growth as a consequence root length of osmoprimed seed maintain its growth though the media was salt stressed. The considerable root length in the treated seeds might be due to increased metabolic activities where salinity stress did not strongly hamper the root growth. This trend of the present result was in agreement with the findings of Mohammadi and Amiri [53]. Moghanibashiet al. [55] also reported that as drought and/or salinity levels increased, root length reduced but the priming treatments clearly boosted the parameter of sunflower under normal and stress conditions.

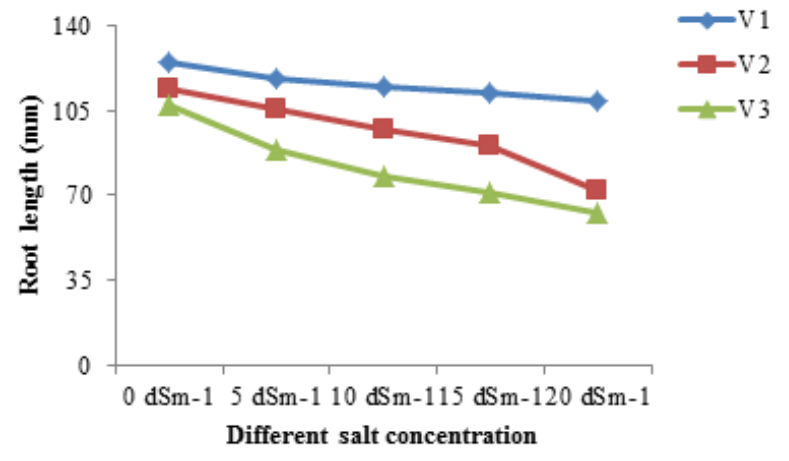

Figure 3. Effect of different salt concentration on the root length of primed wheat cultivars $\left(\operatorname{LSD}_{(0.01)}=6.77,7.02,8.29,6.65\right.$ and 6.65 at 0,5 , 10,15 and $20 \mathrm{dSm}^{-1}$, respectively) $\mathrm{V}_{1}=$ ESWYT $-5, \mathrm{~V}_{2}=$ ESWYT -6 and $\mathrm{V}_{3}=$ BARI gom 28

\subsection{Shoot Dry Weight}

The shoot dry weight of osmoprimed wheat genotypes varied significantly by different salinity stress conditions (Figure 4). There were different extent of reduction was observed of shoot dry weight of wheat genotypes with the increasing of salt stress. Wheat genotype ESWYT-5 showed better tolerance capability under different salt stress conditions and BARI Gom 28 showed the most susceptibility towards the saline stress conditions, ESWYT-6 wheat genotype moderately performed in the context of shoot dry weight. The maximum shoot dry weight $(0.037 \mathrm{mg})$ was received from wheat genotype ESWYT-5 $0 \mathrm{dSm}^{-1}$ salt concentrations and the minimum shoot dry weight $(0.011 \mathrm{mg})$ was received from wheat genotype BARI Gom 28 at $20 \mathrm{dSm}^{-1}$ salt concentrations. As the salinity stress reduce the seedling length of comparatively sensitive wheat genotypes due to retardation of cell division and elongation, following the trend the dry weight of shoots also decreased. But priming presumably permitted some repairs of damaged to membrane caused by deterioration by salinity stress and exerted better germination pattern and higher vigor level than comparatively sensitive genotypes [48]. The refinement in germination and vigor of standard/low-vigor seed might be due to preserve transportation of food material, trigger and re-synthesis of some enzymes, DNA and RNA synthesis start during osmotic priming under stress condition. Removing of obstacle speed up the germination of seed ultimately produced the vigorous shoot and increased shoot dry weight of wheat genotypes [4]. Khalil et al. [61] observed that dry matter yield increased with each increment of priming under normal and stress condition. Inhibition of seedling dry weight due to salt stress should be overcome by using PEG 6000 as osmopriming treatments in soybean. 


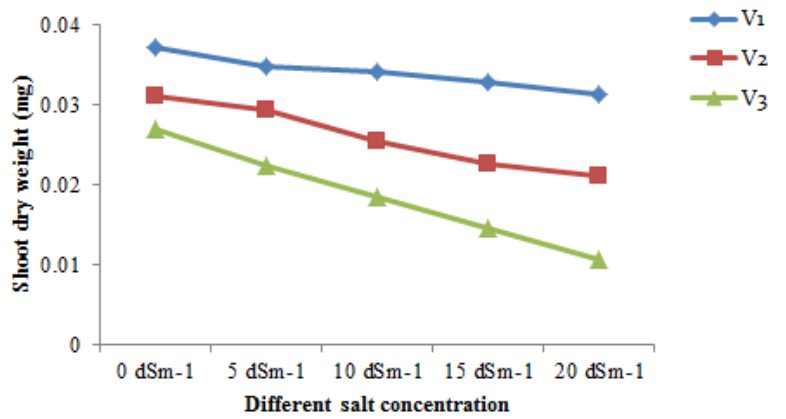

Figure 4. Effect of different salt concentration on the shoot dry weight of primed wheat cultivars $\left(\operatorname{LSD}_{(0.01)}=0.01,0.01,0.01,0.01\right.$ and 0.01 at 0 , $5,10,15$ and $20 \mathrm{dSm}^{-1}$, respectively) $\mathrm{V}_{1}=$ ESWYT $-5, \mathrm{~V}_{2}=$ ESWYT -6 and $\mathrm{V}_{3}=$ BARI gom 28

\subsection{Root Dry Weight}

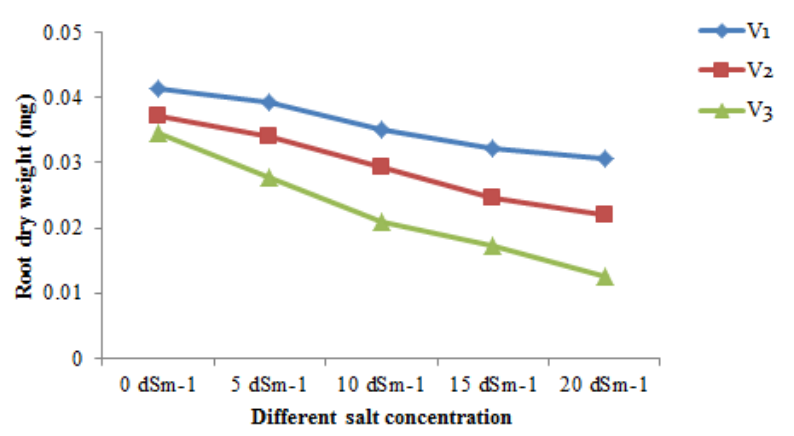

Figure 5. Effect of different salt concentration on the root dry weight of primed wheat cultivars $\left(\operatorname{LSD}_{(0.01)}=0.01,0.01,0.01,0.01\right.$ and 0.01 at 0,5 , 10,15 and $20 \mathrm{dSm}^{-1}$, respectively) $\mathrm{V}_{1}=$ ESWYT $-5, \mathrm{~V}_{2}=$ ESWYT -6 and $\mathrm{V}_{3}=$ BARI gom 28

The Root dry weight of osmoprimed wheat genotypes varied significantly by different salinity stress conditions (Figure 5). There were different extent of reduction was observed of root dry weight of wheat genotypes with the increasing of salt stress. In case of root dry weight, wheat genotype ESWYT-5 showed better tolerance capability under different salt stress conditions and BARI Gom 28 showed the most susceptibility towards the saline stress conditions, ESWYT-6 wheat genotype moderately performed. The maximum root dry weight $(0.041 \mathrm{mg})$ was received from wheat genotype ESWYT-5 $0 \mathrm{dSm}^{-1}$ salt concentrations and the minimum root dry weight $(0.012$ $\mathrm{mg}$ ) was received from wheat genotype BARI Gom 28 at $20 \mathrm{dSm}^{-1}$ salt concentrations. Dry weight is the consequence of plant physiological and biological activity. Under salt stress condition marked reduction was observed of this parameter in comparatively sensitive genotypes $[62,63,64]$. Priming presumably permitted some repairs of damaged to membrane caused by deterioration by salinity stress and exerted better germination pattern and higher vigor level than comparatively sensitive genotypes [48]. Removing of obstacle speed up the germination of seed ultimately produced the vigorous shoot and increased shoot dry weight of wheat genotypes [4]. Khalil et al. [61] observed that dry matter yield increased with each increment of priming under normal and stress condition. Inhibition of seedling dry weight due to salt stress should be overcome by using $\mathrm{PEG}_{6000}$ as osmopriming treatments in soybean.

\subsection{Relative Water Content}

Relative water content of osmoprimed wheat genotypes significantly affected by different level of salinity stress conditions (Figure 6). The relative water content of primed wheat genotypes was decreased in different extent with increasing the salinity stress. Under different salinity levels wheat genotype ESWYT-5 showed maximum tolerance capability and the magnitude of reduction was slow compare to that of other two genotypes where as BARI Gom 28 showed maximum susceptibility and the magnitude of reduction was rapid compare to that of other two genotypes. Wheat genotype ESWYT-6 moderately performed under different saline levels. The result of the experiment revealed that, the maximum relative water content $(89.13 \%)$ was recorded from wheat genotype ESWYT-5 at $0 \mathrm{dSm}^{-1}$ salt concentrations followed by ESWYT-6 $\left(\mathrm{V}_{2}\right)(82.76 \%)$ and the minimum relative water content(44.88\%) was recorded from BARI Gom 28 at 20 $\mathrm{dSm}^{-1}$ salt concentrations. Under salt stress condition tolerance plant can grow vigorously, minimize the salt uptake and maximize potential salt load per unit area by their compartmentalization technique and provide better water use efficiency thus plant growth not hampered [65]. Moreover, the osmopriming agent (PEG) triggered this technique for optimum water use efficiency and higher the relative water content was recorded for salt tolerance wheat genotype. On the other hand, in the same condition sensitive plant could not uptake enough water which seemed to drought condition and this drought condition exhibited large reductions in relative water content and water potential in leaf Nayyar and Gupta [66], Decovet al. [67] and Li and Van Staden [68]. RWC was significantly reduced under saline stress condition, but in case of primed seed with $10 \%$ PEG solution the RWC was comparatively higher.

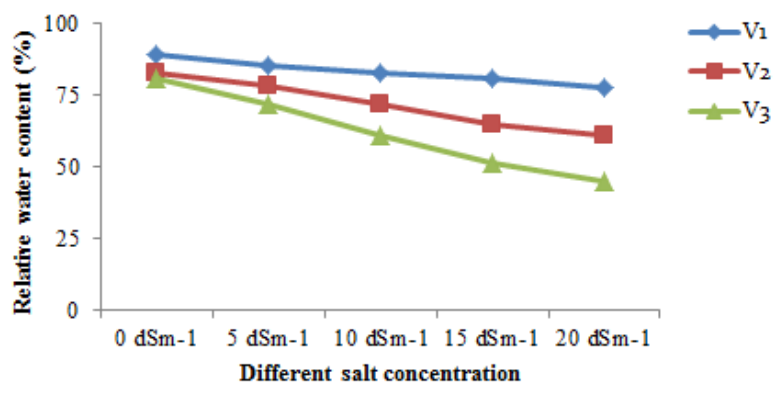

Figure 6. Effect of different salt concentration on the relative water content of primed wheat cultivars $\left(\operatorname{LSD}_{(0.01)}=4.06,4.23,2.56,3.45\right.$ and 3.69 at $0,5,10,15$ and $20 \mathrm{dSm}^{-1}$, respectively) $\mathrm{V}_{1}=$ ESWYT $-5, \mathrm{~V}_{2}=$ ESWYT -6 and $\mathrm{V}_{3}=$ BARI gom 28 


\subsection{Water Saturation Deficit}

Water saturation deficit of osmoprimed wheat genotypes significantly affected by different level of salinity stress conditions (Figure 7). There is an inverse relationship between relative water content and water saturation deficit. The genotype showed more salt susceptibility scored more water saturation deficit. The water saturation deficit of primed wheat genotypes was gradually increased with increasing the salinity stress. The result of the experiment revealed that, under different salinity levels wheat genotype ESWYT-5 showed maximum tolerance capability and the magnitude of water saturation deficit was lowest (10.87) at $0 \mathrm{dSm}^{-1}$ saline concentration compare to that of other two genotypes where as BARI Gom 28 showed maximum susceptibility and the water saturation deficit was maximum (55.12) at $20 \mathrm{dSm}^{-1}$ salt concentration. Wheat genotype ESWYT-6 moderately performed under different saline levels. Water saturation deficit is the opposite character of relative water content. So, presumably the water saturation deficit was higher for salinity sensitive genotype and vice versa. Due to lack of compartmentalization technique, the salinity sensitive cultivars fail to uptake enough water necessary for running the physiological process smoothly under salt stress condition, thus there will be a huge water deficit occur in sensitive cultivars than the tolerance cultivars. Similar result was reported by Baqueet al. [38] but osmopriming might help to recover this physiological damage and minimize the water saturation deficit.

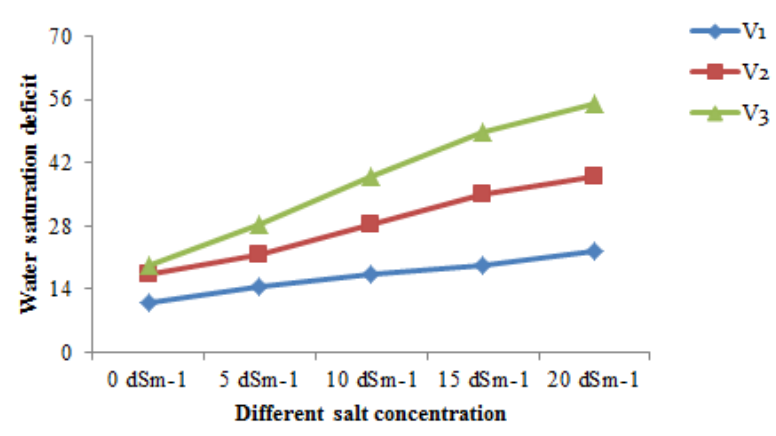

Figure 7. .Effect of different salt concentration on the water saturation deficit of primed wheat cultivars $\left(\operatorname{LSD}_{(0.01)}=1.46,1.72,2.23,3.03\right.$ and 2.46at $0,5,10,15$ and $20 \mathrm{dSm}^{-1}$, respectively) $\mathrm{V}_{1}=$ ESWYT $-5, \mathrm{~V}_{2}=$ ESWYT -6 and $\mathrm{V}_{3}=$ BARI gom 28

\subsection{Water Retention Capacity}

Water retention capacity of osmoprimed wheat genotypes significantly affected by different level of salinity stress conditions (Figure 8). The water retention capacity of primed wheat genotypes was decreased gradually with increasing the salinity stress. Under different salinity levels wheat genotype ESWYT-5 showed maximum tolerance capability and the magnitude of reduction was slow compare to that of other two genotypes whereas BARI Gom 28 showed maximum susceptibility and the magnitude of reduction was rapid compare to that of other two genotypes. Wheat genotype ESWYT-6 moderately performed under different saline levels. The result of the experiment revealed that, the maximum water retention capacity (22.32) was recorded from wheat genotype ESWYT-5 at $0 \mathrm{dSm}^{-1}$ salt concentrations followed by ESWYT-6 $\left(\mathrm{V}_{2}\right)$ (20.73) and the minimum water retention capacity (7.51) was recorded from BARI Gom 28 at $20 \mathrm{dSm}^{-1}$ salt concentrations. The tolerance osmoprimed cultivars have the capacity to uptake water under salt stress condition than the osmoprimed sensitive ones and gained the maximum turgid weight, in consequence they gained the maximum water retention capacity. The result also coincides with the result of Sangakkaraet al. [69]. Osmopriming helps to activate the metabolic enzymes responsible for germination of seed before germination takes place, so the seedling from osmoprimed seed got advantages to retain enough water under salt stress condition.

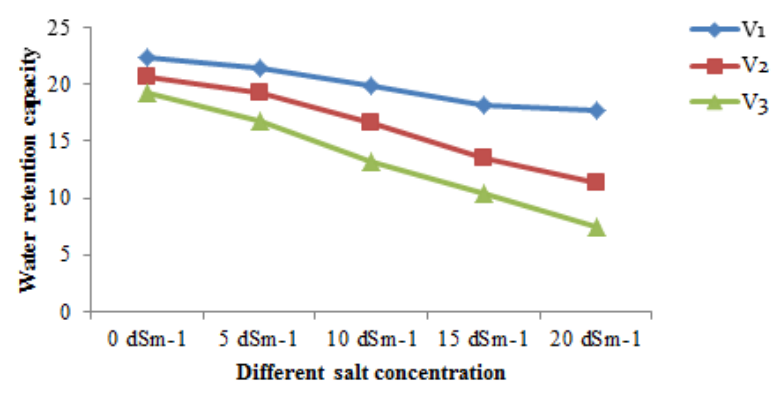

Figure 8. Effect of different salt concentration on the water retention capacity of primed wheat cultivars $\left(\operatorname{LSD}_{(0.01)}=1.61,1.19,1.28,1.31\right.$ and 1.12 at $0,5,10,15$ and $20 \mathrm{dSm}^{-1}$, respectively) $\mathrm{V}_{1}=$ ESWYT $-5, \mathrm{~V}_{2}=$ ESWYT -6 and $\mathrm{V}_{3}=$ BARI gom 28

\subsection{Germination Coefficient}

Germination coefficient of osmoprimed wheat genotypes significantly varied by different level of salinity stress conditions (Figure 9). The germination coefficient of primed wheat genotypes was decreased in different extent with increasing the salinity stress. Under different salinity levels wheat genotype ESWYT-5 showed maximum tolerance capability and the magnitude of reduction was slow compare to that of other two genotypes whereas BARI Gom 28 showed maximum susceptibility and the magnitude of reduction was rapid compare to that of other two genotypes in context of germination coefficient. Wheat genotype ESWYT-6 moderately performed under different saline levels. The result of the experiment revealed that, the maximum germination coefficient (18.01) was recorded from wheat genotype ESWYT-5 at $0 \mathrm{dSm}^{-1}$ salt concentrations followed by ESWYT- $6\left(\mathrm{~V}_{2}\right)(17.80)$ and the minimum water retention capacity (11.48) was recorded from BARI Gom 28 at $20 \mathrm{dSm}^{-1}$ salt concentrations. The reduction of germination rate with the increasing of salt 
concentration occurred for salt sensitive cultivars which caused reduction of coefficient of germination under salt stress condition. Similar results were reported by Akbarimoghaddamet al. [62], Dattaet al. [57], Mujeebet al. [41], Rahmanet al. [70] and Singh et al. [71]. But when the seed was primed with osmoticum (PEG), it reduced the negative impact of salt stress and maintains a improve performance of germination coefficient. Seed priming resulted from anti-oxidant increment as glutathione and ascorbate in the seed. These enzymes trigger germination speed via reduction of lipid peroxidation activity; as a result germination coefficient was higher in osmoprimed salt tolerance genotypes compare to that of sensitive one. Osmopriming of Italian ryegrass (Lolium multiflorum) and sorghum (Sorghum bicolor) seeds with $20 \% \mathrm{PEG}_{8000}$ for 2 $\mathrm{d}$ at $10^{\circ} \mathrm{C}$ enhanced germination coefficient of wheat genotypes under water stress, water logging, cold stress and saline conditions. [55,72]. It has been evident that priming had resulted in more germination speed especially in salt and drought stress, saline stress and low temperatures in sorghum, sunflower, and melon $[39,73,74]$.

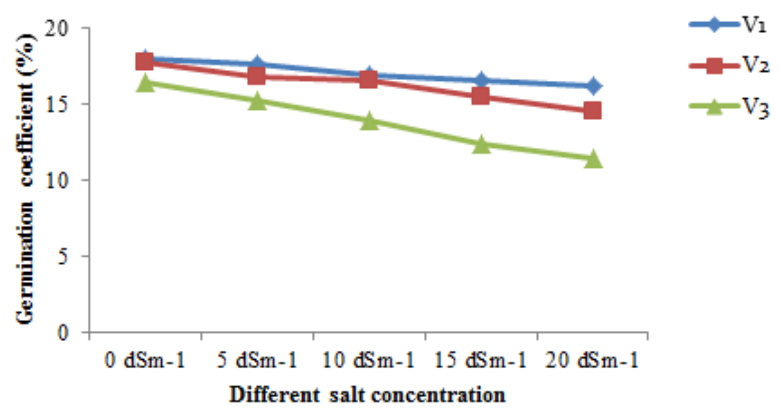

Figure 9. Effect of different salt concentration on the germination coefficient of primed wheat cultivars $\operatorname{LSD}_{(0.01)}=0.73,0.62,0.66,0.62$ and 0.78 at $0,5,10,15$ and $20 \mathrm{dSm}^{-1}$, respectively) $\mathrm{V}_{1}=$ ESWYT-5, $\mathrm{V}_{2}=$ ESWYT -6 and $\mathrm{V}_{3}=$ BARI gom 28

\subsection{Vigour Index}

Vigour index of osmoprimed wheat genotypes significantly varied by different level of salinity stress conditions (Figure 10). The vigour index of primed wheat genotypes was decreased in different extent with increasing the salinity stress. Under different salinity levels wheat genotype ESWYT-5 showed maximum tolerance capability and the magnitude of reduction was slow compare to that of other two genotypes whereas BARI Gom 28 showed maximum susceptibility and the magnitude of reduction was rapid compare to that of other two genotypes in context of vigour index. Wheat genotype ESWYT-6 moderately performed under different saline levels. The results revealed that, the maximum vigour index (264.70) was recorded from wheat genotype ESWYT-5 at $0 \mathrm{dSm}^{-1}$ salt concentrations followed by ESWYT-6 $\left(\mathrm{V}_{2}\right)(232.40)$ and the minimum water retention capacity (100.10) was recorded from BARI Gom 28 at 20 $\mathrm{dSm}^{-1}$ salt concentrations. As drought and/or salinity levels increased, vigour reduced but the priming treatments clearly improved the parameter under drought and salinity conditions so these treatments can be used to improve seed performance of sunflower under normal and stress [55]. Similar trends were reported by Moud and Maghsoudi [56], Singh et al. [71], Karimet al. [75], Baqueet al. [33], Maitiet al. [76] who reported that seed priming increases the seedling vigor of several vegetable crops and concerning sponge gourd, osmo-priming increased seedling vigor. The advancement in germination and vigor of soybean plant was probably due to the reserve mobilization of food material, activation and re-synthesis of some enzymes, DNA and RNA synthesis started during osmotic priming [77]. There might be the possibility that similar germination responsive genes may be activated because of chitosan priming under osmotic stress. Osmopriming of Italian ryegrass (Lolium multiflorum) and sorghum (Sorghum bicolor) seeds with $20 \% \mathrm{PEG}_{8000}$ for $2 \mathrm{~d}$ at $10^{\circ} \mathrm{C}$ increased the vigor index under water and salt stress condition.

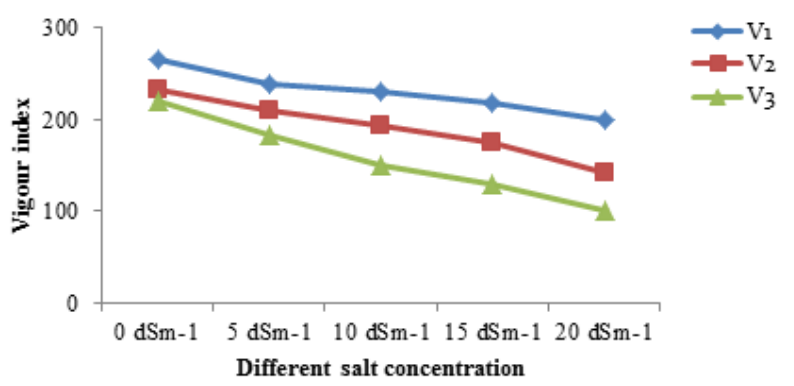

Figure 10. Effect of different salt concentration on the vigour index of primed wheat cultivars $\left(\operatorname{LSD}_{(0.01)}=17.37,13.76,17.18,10.89\right.$ and 12.88 at $0,5,10,15$ and $20 \mathrm{dSm}^{-1}$, respectively) $\mathrm{V}_{1}=$ ESWYT-5, $\mathrm{V}_{2}=$ ESWYT -6 and $\mathrm{V}_{3}=$ BARI gom 28

\section{Conclusions}

Considering the above findings achieved from the present study it may be concluded that osmopriming has a positive significant effect on germination, seedling growth and water relation behavior on wheat seed under salt stress condition. Among 3 wheat genotypes ESWYT-5 wheat genotypes was performed better in most of the germination, seedling growth and water relation behaviors of wheat followed by ESWYT-6; and BARI Gom 28 showed consistently poor performance under salt stress condition. The germination, seedling growth and water relation behavior of wheat cultivars decreased with increasing of salt concentrations but the decrease was gradually slow. This might be due to the osmoprimed agent (PEG) which triggers the germination, seedling growth and water relation behavior of wheat genotypes though under salt stress conditions. So, it can be concluded that priming 
helps to improve the germination, seedling growth and water relation behaviors of wheat seed under salt stress condition.

\section{Acknowledgements}

This research work was fully financed by BAS-USDA, PALS, project no. CR-09, Bangladesh Academy of Science, National Science and Technology Museum Bhaban, Agargaon, Dhaka-1207, Bangladesh.

\section{REFERENCES}

[1] WHEAT. Wheat: vital grain of civilization and food security. 2013. Annual Report, CGIAR Research Program on Wheat, Mexico, 2014.

[2] M. Quamruzzaman, M. J. Ullah, M. J. Rahman, R. Chakraborty, M. M. Rahman and M. G. Rasul. Organoleptic assessment of Groundnut (ArachishypogaeaL.) as influenced by boron and artificial lightening at night. World J. Agric. Sci. 12(1): 01-06, 2016.

[3] G. J. M. Beckers and U. Conrath. Priming for stress resistance: from the lab to the field. Curr. Opin. Plant Biol. 10: 425-431, 2007.

[4] S. M. A. Basra, M. Farooq and R. Tabassum. Physiological and biochemical aspects of seed vigour enhancement treatments in fine rice (Oryza sativa L.). Seed Sci. Technol. 33: $623-628,2005$.

[5] D. J. Cantliffe. Seed Enhancements. J. Acta. Horticulturae. 607: 53-59, 2003.

[6] A. A. Powell, L. J. Yule, H. C. Jingh and P. C. Groots. The influence of aerated hydration seed treatment on the seed longevity as assessed by the viability equation. J. Exp. Bot. 51: 2031-2043, 2000.

[7] A. G. Taylor, P. S. Allen, M. A. Bennett, K. J. Bradford, J. S. Burris and M. K. Misra. Seed enhancements. J. Seed Sci. Res. 8: 245-256, 1998.

[8] F. Carbineau and D. Come. Priming: a technique for improving seed quality. J. Seed Testing Int. p. 132, 2006.

[9] M. Ashraf and M. R. Foolad. Pre-sowing seed treatment a shotgun approach to improve germination, plant growth, and crop yield under saline and non-saline conditions. J. Adv. Agron. 88: 223-271, 2005.

[10] I. A. Ungar. Seed germination and seed-bank ecology of halophytes. In: Seed Development and Germination, J. Kigel and G. Galili, Eds., Marcle and Dekker, New York, NY, USA, 1995.

[11] C. A. Jaleel, R. Gopi, P. Manivannan and R. Panneerselvam. Antioxidative potentials as a protective mechanism in Catharanthusroseus(L.) plants under salinity stress. TurkishJ. Bot. 31(3): 245-251, 2007.

[12] M. Almansouri, J. M. Kinet and S. Lutts. Effect of salt and osmotic stresses on germination in durum wheat
(Triticumdurum Desf.). PlantSoil. 231(2): 243-254, 2001.

[13] C. Ghoulam and K. Fares. Effect of salinity on seed germination and early seedling growth of sugar beet (Beta vulgaris L.). Seed Sci. Technol. 29(2): 357-364, 2001.

[14] Soil Resources Development Institute (SRDI). Saline Soils of Bangladesh; SRDI, Ministry of Agriculture: Dhaka, Bangladesh, 2010.

[15] R. Munns. Comparative physiology of salt and water stress. Plant Cell Environ. 25: 239-250, 2002.

[16] M. Ashraf and P. J. C. Harris. Potential biochemical indicators of salinity tolerance in plants. Plant Sci. 166: 3-16, 2004.

[17] Lallu and R. K. Dixit. Salt tolerance of Mustard genotype at seedling stage. Indian J. Plant Physiol.14 (2): 33-35, 2005.

[18] M. R. Ghannadha, M. Omidi, R. A. Shahi and K. Poustini. A study of salt tolerance in genotypes of bread wheat using tissue culture and germination test. Iranian J. Agri. Sci.36 (1): $75-85,2005$.

[19] A. K. Bera, M. K. Pati and A. Bera. Bassionolide ameliorates adverse effect on salt stress on germination and seedling growth of rice. Indian J. Plant Physiol.11 (2): 182-189, 2006

[20] R. K. Agnihotri, L. M. S. Palni and D. K. Pandey. Screening of land races of rice under cultivation in Kumaun Himalayan for salinity stress during germination and early seedling growth. Indian J. Plant Physiol.11 (30): 262-272, 2006.

[21] S. Cha-Um, C. Kirdmanee and Supaibulwatana. Biochemical and physiological responses of thai jasmine rice (Oryza sativa L. sp. Indicacv. KOML 105) to salt stress. Sci. Asia. 30: 247-253, 2004.

[22] C. A. Parera and D. J. Cantliffe. Pre-sowing seed priming. J. Hort. Rev. 16: 109-141, 1994.

[23] M. B. McDonald. Seed priming, Black, M., J. D. Bewley, (Eds.), Seed Technology and Its Biological Basis, Sheffield Academic Press, Sheffield, UK. pp. 287-325, 2000.

[24] C. C. Hsu, C. L. Chen, J. J. Chen and J. M. Sung. Accelerated aging-enhanced lipid peroxidation in bitter gourd seeds and effects of priming and hot water soaking treatments. J. Sci. Hort. 98: 201-212, 2003.

[25] H. Y. Wang, C. L. Chen and J. M. Sung. Both warm water soaking and solid priming treatments enhance anti-oxidation of bitter gourd seeds germinated at sub-optimal temperature. J. Seed Sci. Technol. 31: 47-56, 2003.

[26] K. Y. Chiu, C. L. Chen and J. M. Sung. Effect of priming temperature on storability of primed sh-2 sweet corn seed. Crop Sci. 42: 1996-2003, 2002.

[27] I. Capron, F. Corbineua, F. Dacher, C. Job, D. Come and D. Job. Sugar beet seed priming: Effects of priming conditions on germination, solubilization of 11-s globulin and accumulation of LEA proteins. Seed Sci. Res. 10: 243-254, 2000 .

[28] D. Harris, A. Joshi, P. A. Khan, P. Gothakar and P. S. Sodhi. On-farm seed priming in semi-arid agriculture: 
Development and evaluation in corn, rice and Chickpea in India using participatory method. Expt. Agric. 35: 15-29, 1999.

[29] W. Chivasa, D. Harris, C. Chiduza and P. Nymudeza. Agronomic practices, major crops and farmer's perceptions of good stand establishment in musikavanhu. J. Appl. Sci. 4: 109-125, 1998.

[30] K. C. Jisha, K. Vijayakumari and J. T. Puthur. Seed priming for abiotic stress tolerance: an overview. Acta. Physiol. Plant. 35(5): 1381-1396, 2013.

[31] J. M. Lin and J. M. Sung. Pre-sowing treatments for improving emergence of bitter gourd seedlings under optimal and sub-optimal temperatures. J. Seed Sci. Technol. 29: 39-50, 2001.

[32] M. Faijunnahar, A. Baque, M. A. Habib andH. M. M. T. Hossain. Polyethylene glycol (PEG) induced changes in germination, seedling growth and water relation behavior of wheat genotypes. Univ. J. Plant Sci. 5(4): 49-57, 2017.

[33] A. Baque, M. Nahar, M. Yeasmin, M. Quamruzzaman, A. Rahman, M. J. Azad and P. K. Biswas. Germination behavior of wheat (TriticumaestivumL.) as influenced by polyethylene glycol (PEG). Universal J. Agril. Res. 4(3): 86-91, 2016.

[34] A. O. Demir, A. T. Goksoy, H. Buyukcangaz, Z. M. Turan and E. S. Koksal. Deficit irrigation of sunflower (Helianthus annuusL.) in a sub-humid climate. Irrig. Sci. 24: 279-289, 2006.

[35] M. M. Hasan, M. A. Baque, M. A. Habib, M. Yeasmin, M. A. Hakim. Screening of salt tolerance capability of wheat genotypes under salt stress condition. Univ.J. Agril. Res. 5(4): 235-249, 2017.

[36] L. Copeland. Principle of Seed Science and Technology. Burgess Publishing Company, Minneapolis, Mannishly. pp. 164-165, 1976.

[37] A. A. Abdul-Baki and J. D. Anderson. Viability and leaching of sugars from germinating barley. Crop Sci. 10: 31-34, 1970.

[38] M. A. Baque, M. A. Karim and A. Hamida. Role of potassium on water relation behavior of TriticumastivumL. under water stress conditions. Prog. Agric. 13(1\&2): 71-75, 2002.

[39] M. D. Kaya, G. Okc and Y. C. Atak. Seed treatments to overcome salt and drought stress during germination in sunflower (Helianthus annuusL.). Europ. J. Agron. 24: 291-295, 2006

[40] M. Khajeh-Hosseini, A. A. Powell and I. J. Bimgham. The interaction between salinity stress and seed vigor during germination of soybean seeds. Seed Sci. Technol. 31: 715-725, 2003.

[41] U. R. Mujeeb, U. A. Soomro, M. Z. U. Haq and S. Gul. Effects of $\mathrm{NaCl}$ salinity on wheat (TriticumaestivumL.) cultivars. World J. Agril. Sci. 4(3): 398-403, 2008.

[42] G. R. Cramer, G. J. Alberico and C. Schmidt. Salt tolerance is not associated with the sodium accumulation of two maize hybrids. Australian J. Plant Physiol. 21: 675-692, 1994.

[43] M. A. Khan, I. A. Ungar and A. M. Showalter. Effects of sodium chloride treatments on growth and ion accumulation of the halophyte HaloxylonrecurvumCommun. Soil Sci. Plant Anal. 31: 2763-2774, 2000.

[44] M. Ashraf and J. W. Oleary. Responses of some newly developed salt-tolerant genotypes of spring wheat to salt stress. Yield components and ion distribution. J. Agron. Crop Sci.176: 91-101, 1996.

[45] R. K. Sairam, R. K. Veerabhadra and G. C. Srivastava. Differential response of wheat genotypes to long term salinity stress in relation to oxidative stress, antioxidant activity and osmolyte concentration. Plant Sci. 163: 1037-1046, 2002.

[46] A. Ajouri, A. Haben and M. Becker. Seed priming enhances germination and seedling growth of barley under conditions of $\mathrm{P}$ and $\mathrm{Zn}$ deficiency. J. Plant Nutri. Soil Sci. 167: 630-636, 2004.

[47] H. R. Rowse. Drum Priming- A non-osmotic method of priming seeds. Seed Sci. Technol. 24: 281-294, 1995.

[48] S. Ruan, Q. Xue and K. Tylkowska. The influence of priming on germination of rice Oryza sativa L. seeds and seedling emergence and performance in flooded soil. Seed Sci. Technol. 30: 61-67, 2002.

[49] K. Chen and R. Arora. Dynamics of the antioxidant system during seed osmopriming, post-priming germination and seedling establishment in spinach (Spinaciaoleracea). Plant Sci. 180: 212-220, 2011.

[50] M. Yamur and D. Kaydan. Alleviation of osmotic stress of water and salt in germination and seedling growth of triticale with seed priming treatments. Afr. J. Biotechnol., 7(13): 2156-2162, 2008.

[51] M. B. Hassanpouraghdam, P. J. Emarat and A. N. Farsad. The effect of osmo-priming on germination and seedling growth of Brassica napusL. under salinity conditions. J. Food Agric. Environ. 7(2): 620-622, 2009.

[52] M. Farooq, S. M. A. Barsa and A. Wahid. Priming of field-sown rice seed enhances germination, seedling establishment, allometry and yield. Plant Growth Regul. 49(2): 285-294, 2006.

[53] G. R. Mohammadi and F. Amiri. The effect of priming on seed performance of canola (Brassica napusL.) under drought stress. American-Eurasian J. Agric. and Environ. Sci. 9(2): 202-207, 2010.

[54] S. S. Lee and J. H. Kim. Total sugars, $\alpha$-amylase activity and germination after priming of normal and aged rice seeds. Korean J. Crop Sci. 45: 108-111, 2000.

[55] M. Moghanibashi, H. Karimmojeni and P. Nikneshan. Seed treatment to overcome drought and salt stress during germination of sunflower (Helianthus annuusL.). J. Agrobiol. 30(2): 89-96, 2013.

[56] A. M. Moud and K. Maghsoudi. Salt stress effects on respiration and growth of germinated seeds of different wheat (TriticumaestivumL.) cultivars. World J. Agril. Sci.4(3): 351-358, 2008.

[57] J. K. Datta, S. Nag, A. Banerjee and N. K. Mondal. Impact of salt stress on five varieties of Wheat (TriticumaestivumL.) cultivars under laboratory condition. J. App. Sci. Environ.13(3): 93-97, 2009. 
[58] A. Tarmatt and R. Munns. Use of concentrated micronutrient solution to separate osmotic from $\mathrm{NaCl}$ specific effects on plant growth. Australian J. Plant Physiol.13: 509-522, 1986.

[59] J. C. Dager, H. Bhagwan and Y. Kumar. Effect of growth performance and biochemical content of Salvadorapersicawhen irrigated with water of different salinity. Indian J. Plant Physiol.9(3): 234-238, 2004.

[60] M. A shraf, and S. Abu-Shakra. Wheat seed germination under low temperature and moisture stress. J. Agron.70: $135-139,1978$.

[61] S. K. Khalil, S. Khan, A. Rahman, A. Z. Khan, I. H. Khalil, W. S. Amanullah, F. Mohammad, S. Nigar, M. Zubair, S. Parveen and A. Khan. Seed priming and phosphorus application enhance phenology and dry matter production of wheat. Pakistan J. Bot. 42(3): 1849-1856, 2010.

[62] H. Akbarimoghaddam, M. Galavi, A. Ghanbari and N. Panjehkeh. Salinity effects on seed germination and seedling growth of bread wheat cultivars. Trakia J. Sci. 9(1): 43-50, 2011.

[63] M. A. Bhatti, Z. Ali, A. Bakhsh, A. Razaq and A. R. Jamali. Screening of wheat lines for salinity tolerance. Int. J. Agril. Biol.6(4): 627-628, 2004.

[64] Y. Rumena. Physiology of rice genotypes under saltstress conditions. A PhD. Thesis. Department of Crop Botany, BSMRAU, Salna, Gazipur, 2006.

[65] T. J. Flower, F. M. Salma and A. R. Yeo. Water use efficiency in rice in relation to plant. Plant cell Environ.11: 453-459, 1998.

[66] H. Nayyar, D. Gupta. Differential sensitivity of $\mathrm{C}_{3}$ and $\mathrm{C}_{4}$ plants to water deficit stress: association with oxidative stress and antioxidants. Environ.Expt. Bot. 58: 106-113, 2006.

[67] I. Decov, T. Tsonev, I., Yordanov. Effects of water stress and high temperature stress on the structure and activity of photosynthetic apparatus of Zea mays and Helianthus annuus. Photosynthetica. 38: 361-366, 2000.
[68] L. Li, J. Van Staden. Effects of plant growth regulators on the antioxidant system in callus of two maize cultivars subjected to water stress. Plant Growth Regul. 24: 55-66, 1998.

[69] U. R. Sangakkara, U. A. Harteing and J. Nosberger. Response of root branching and shoot water potentials of French bean (Phaseolus vulgaris L.) to soil moisture and fertilizer potassium. J. Agron. Crop Sci.177: 165-173, 1996.

[70] M. Rahman, S. A. Kayani, S. Gul. Combined effects of temperature and salinity stress on corn cv. Sunahry. Pakistan J. Bio. Sci. 3(9): 1459-1463, 2000.

[71] A. K. Singh, V. Prakash, and E. V. D. Sastry. Effect of salinity stress on seed germination and seeding growth of wheat. Agric. Sci. Digestion. 20(2): 96-98, 2000

[72] S. N. Hur. Effect of osmoconditioning on the productivity of Italian ryegrass and sorghum under suboptimal conditions. Korean J. Anim. Sci. 33: 101-105, 1991.

[73] N. Sivritepe, H. O. Sivritepe and A. Eris. The effects of $\mathrm{NaCl}$ priming on salt tolerance in melon seedling grown under saline conditions. ScientiaHolticuturae. 97: 229-237, 2003.

[74] S. Foti, S. L. Cosentino, C. Patane and G. M. D'Agosta. Effect of osmoconditioning upon seed germination of Sorghum (Sorghom bicolor L) under low temperatures. Seed Sci. Technol. 30: 521-533, 2002.

[75] M. A. Karim, N. Utsunomiya and S. Shigenaga. Effect of sodium chloride on germination and growth of hexaploid triticale at early seedling stage. Japan J. Crop Sci.61(2): 279-284, 1992

[76] R. K. Maiti, P. Vidyasagar, D. Rajkumar, A. Ramaswamy and H. G. Rodriguez. Seed Priming improves seedling vigor and yield of few vegetable crops. Int. J. Bio-res. Stress Manag. 2(1): 125-130, 2011.

[77] H. Sadeghi, F. Khazaei, L. Yari and S. Sheidaei. Effect of seed osmopriming on seed germination behavior and vigor of soybean (Glycine max L.). J. Agric. Biol. Sci. 6(1): 39-43, 2011. 